\title{
SEROPREVALENCE OF EQUINE BRUCELLOSIS: FIRST REPORT IN BANGLADESH
}

\author{
M. K. S. A. Millat ${ }^{1}$, N. M. Shafy ${ }^{1}$, S. T. Sharmy ${ }^{1}$, F. Yeasmin ${ }^{1}$, M. F. Karim ${ }^{1}$, M. A. Ehsan ${ }^{1}$, R. R. Sarker ${ }^{1,2}$, \\ F. Khatun ${ }^{2}$, M. A. Wares ${ }^{2}$, M. M. Hasan ${ }^{1}$, I. Nishidate ${ }^{2}$ and M. S. Rahman ${ }^{1,2}$ \\ ${ }^{1}$ Department of Medicine, Faculty of Veterinary Science, Bangladesh Agricultural University, Mymensingh, \\ 2202, Bangladesh; ${ }^{2}$ Graduate School of Bio-Application and Systems Engineering, Tokyo University of \\ Agriculture and Technology, 2-24-16, Naka-cho, Koganei, Tokyo, 184-8588, Japan
}

\begin{abstract}
Despite the endemicity of brucellosis, there is no report on the equine brucellosis in Bangladesh. The Rose Bengal Test (RBT) was used to determine the seroprevalence of Brucella antibodies amongst 112 horses from different areas of Bangladesh. The overall seroprevalence of equine brucellosis was $1.79 \%$.The prevalence recorded in Ghatail area was $3.45 \%$ and there was no positive reactor in Shakipur and Savar areas. Sex wise prevalence showed that the prevalence was 3.08\%in female and $0.00 \%$ in male horse. Only the adult ( $>3$ years of old) horses showed the positive RBT reaction $(2.35 \%)$, whereas young $(<3$ years of old) horses did not showed positive RBT reaction. The present study reports the first serological prevalence of Brucella infection in horses in Bangladesh. There is need for the inclusion of horses in brucellosis surveillance and control strategies in Bangladesh to safeguard people from high risk.
\end{abstract}

Keywords: Brucella, horse, RBT, Bangladesh.

\section{INTRODUCTION}

Brucellosis is a disease of sexually matured animals that has a great economic importance. Brucellosis is an enormous problem throughout the world; it is endemic problem in most countries including Bangladesh (Pappas et al., 2006; Rahman et al., 2011). It alternatively affects the production and reproduction potential of the animal in terms of abortion, infertility and reduction or no production of milk after abortion (Radostits et al., 2000; Rahman et al., 2011, 2012; Roth et al., 2003). Brucellosis affects several mammalian species, including horses (Ribeiro et al., 2008).Brucellosis in domestic and wild horses is caused by Gram-negative facultative intracellular coccobacilli ( 0.5 to $0.7 \mu \mathrm{m}$ wide and 0.6 to $1.5 \mu \mathrm{m}$ long) bacteria of the genus Brucella (Lucero $e t$ al., 2008; OIE, 2009). Three species of Brucella have been identified that's mainly infecting horses: B. abortus, $B$. suis and B. canis. However, B. abortus has been found to be the most common cause of brucellosis in rural horse populations (Ribeiro et al., 2008). The disease is typically transmitted through contact with infected animals or materials, ingestion of raw milk or meat, aborted materials and aerosolized organisms (Alexander $e t$ al., 1981; Godfroid et al., 2004; OIE, 2009).Horses present nonspecific signs such as depression, intermittent fever, muscles stiffness, atlantal and carpal bursitis, tenosynovitis, osteomyelitis, osteoarthritis, and rare reproductive disorders (Ribeiro et al., 2008). Equine brucellosis has also been associated with fistulous withers (Ocholi et al., 2004; Cvetnic et al., 2005).

Brucellosis has zoonotic potentiality. From public health view point, it is considered to be an occupational disease that mainly affects slaughter-house workers, butchers, and veterinarians or those people directly contract with the affected animals (Acha and Szyfer, 1987). The data regarding equine brucellosis appears to be exiguous unlike ruminants in Bangladesh. To the best of knowledge there is no published report of the sero-prevalence of brucellosis in horse in Bangladesh. Therefore, the following study was carried out for the diagnosis of brucellosis in horse with the objective of the estimation of seroprevalence of brucellosis in horse using RBT.

*Corresponding e-mail address: prithu102@yahoo.co.uk 


\section{METHODS AND MATERIALS}

A total of 112 blood samples were collected from horse populated areas of Dhaka and Tangail districts of Bangladesh. In Dhaka, 34 horse blood sample from Savar. In Tangil58 from Ghatail and 20 samples from Sokhipur were collected. Venous blood sample were conveniently and aseptically obtained from sexually matured horse. The epidemiological data regarding the age, sex, geographical location etc. were collected from the animal owner. All the blood samples were processed for sera followed by preservation in refrigerator and then tested by Rose Bengal Test (RBT) as a screening test. The study was conducted for a period of 6 months from January 2017 to June 2017 in the Department of Medicine, Faculty of Veterinary Science, Bangladesh Agricultural University, Mymensingh.

\section{Blood and sera samples collection}

After controlling the animal blood was collected from jugular vein aseptically. About 5-7 ml of blood was collected from jugular vein of each horse with the help of sterile disposable syringe and needle. Then the blood was taken into test-tube and was kept undisturbed on jar with ice water for at least 1 hour at room temperature in slightly inclined position to facilitate clotting and separation of serum. After this period the sera sample were transferred to the sterilized labeled eppendorf tube and stored at $-20^{\circ} \mathrm{C}$ until used.

\section{RBT}

The diagnostic antigen preparation and test was done according to the procedure of Manufacturer (Instituto de Salud Tropical Universidad de Navarra @ Edificio CIMA AvdaPioXII, 55 E-31008 Pamplona, Spain). Approximate number (112) of processed test sample (serum), sufficient antigen, positive and negative control sera for a day's testing were removed from refrigeration and kept for adjusting at room temperature $\left(25^{\circ} \mathrm{C}\right)$ for 30 minutes.30 $\mu 1$ of each serum to be tested was placed on a previously cleaned fine plastic plate circled approximately $1.5 \mathrm{~cm}$ in diameter. Then the bacterial antigen was shacked gently for proper mixing and $30 \mu 1$ of antigen put beside each of the sera on the plastic plate circle. The antigen and sera was mixed on the plate with a plastic stirrer and spread over the area enclosed by the circle. Then the plate was placed on a mechanical rotator at 90-100rpm for 3-5 minutes and the reading was taken immediately by the help of magnifying glass and also necked eye.

\section{Data processing and Statistical analysis}

The data obtained in the study with respect to area, age, sex of animals was processed by Microsoft Excel and analyzed by SPSS version 20.0 (Statistical Package for Social Services). Pearson chi-square test was done to determine the susceptibility of the sex (male/female), area and age wise prevalence to brucellosis. Significance was calculated between $1 \%$ and $5 \%$ level.

\section{RESULTS AND DISCUSSION}

Out of total 112 samples, 2 showed positive reactions and the overall seroprevalence of equine brucellosis was $1.79 \%$ (Table 1). The prevalence of equine brucellosis in present study is much more lower than the prevalence reported by Solmaz et al. (2004) and Wadood et al. (2009) who reported $20.7 \%$ and $60.56 \%$, respectively by Rose Bengal Test. Area wise seroprevalence was $0.00 \%, 3.45 \%$ and $0.00 \%$ in Savar, Ghatail and Sokhipur, respectively (Table 2). The difference among various sources was not statistically significant. There was no positive reactor in Savar and Sokhipur area which may be due to smaller sample size from these two areas.

Table 1. Overall prevalence of brucellosis of horses based on RBT.

\begin{tabular}{l|c|c|c}
\hline Total number of sample & Positive reactor & Negative reactor & $\%$ of positive reactor \\
\hline 112 & 2 & 110 & 1.79 \\
\hline
\end{tabular}


Table 2. Prevalence of brucellosis of horses based on RBT.

\begin{tabular}{|c|c|c|c|c|c|}
\hline Parameter & Total & $\begin{array}{l}\text { Positive } \\
\text { reactor }\end{array}$ & $\begin{array}{l}\text { Negative } \\
\text { reactor }\end{array}$ & $\begin{array}{c}\% \text { of positive } \\
\text { reactor }\end{array}$ & $\begin{array}{c}\text { Level of } \\
\text { significance }\end{array}$ \\
\hline \multicolumn{6}{|l|}{ Area } \\
\hline Savar & 34 & 0 & 34 & 0.00 & \multirow{3}{*}{ NS } \\
\hline Ghatail & 58 & 2 & 56 & 3.45 & \\
\hline Sokhipur & 20 & 0 & 20 & 0.00 & \\
\hline \multicolumn{6}{|l|}{ Age } \\
\hline Young ( 0 to $<3$ years $)$ & 27 & 0 & 27 & 0.00 & \multirow{2}{*}{ NS } \\
\hline Adult ( $>3$ years to above) & 85 & 2 & 83 & 2.35 & \\
\hline \multicolumn{6}{|l|}{ Sex } \\
\hline Male & 47 & 0 & 47 & 0.00 & \multirow{2}{*}{ NS } \\
\hline Female & 65 & 2 & 63 & 3.08 & \\
\hline
\end{tabular}

NS= Not significant (at $5 \%$ level of significance)

According to age, the all horses were divided into two groups: Young ( 0 to $<3$ years) and Adult ( $>3$ years to above). Age wise prevalence showed that RBT is positive to only adult horses ( $>3$ years to above) with the prevalence of $2.35 \%$ (2/85)but no young ( $<3$ years of old) animal showed such type of positive reaction (Table $2)$.Difference in seroprevalence among various age groups was statistically non significant $(\mathrm{P}>0.05)$. This low prevalence in young animals may be explained on the basis that the animal may harbor the organism without expressing any detectable antibodies until their first parturition or abortion (Wadood et al., 2009). In this study, a total of 47 male horses and 65 female horses were tested from different areas. Among them 2 female horses showed positive reaction to RBT with the prevalence of $3.08 \%$ whereas all male horses showed negative reaction to RBT (Table 2). There was no significant association between sex of horse which is similar with the findings of Muma et al. (2006) and Wadood et al. (2009) who reported that seroprevalence of brucellosis was not associated with sex. But the finding is differed from the findings of Ahmed and Munir (1995) and Solmaz et al. (2004) reported higher prevalence of brucellosis in females than in males. The higher prevalence in female may be due to the fact that females remain in close association with the infected mares, which can infect the healthy ones.

The current study determined the first information on the seroprevalence of Brucella antibodies among the horses in Bangladesh. In the present study, RBPT was conducted because it is widely used as a screening test and also can detect IgG and IgM (Omer et al., 2007). The RBPT is easy to perform, cheap, rapid and highly sensitive but less specific than SAT (Gul and Khan, 2007). Sera negative for RBPT are not tested further. Regular seromonitoring of the horse, culling of positive reactors from breeding program are important to eradicate or control of this zoonotic disease.

\section{ACKNOWLEDGEMENTS}

Authors are grateful to Instituto de Salud Tropical Universidad de Navarra @ Edificio CIMA AvdaPioXII, 55 E-31008 Pamplona, Spain for supplying the RBT antigen and JSPS (Japan Society for the Promotion of Science) for the invitation fellowship to the corresponding author (MS Rahman).

\section{REFERENCES}

1. Acha PN and Szyfer B (1987). Zoonosis and communicable diseases common in man and animals. Pan American Health Organization, $2^{\text {nd }}$ Ed. Washington, USA.

2. Ahmed R and Munir MA (1995). Epidemiological investigations of brucellosis in Pakistan. Pakistan Veterinary Journal 15:169-172.

3. Alexander B, Schnurrenberger P and Brown R (1981). Numbers of Brucella abortus in the placenta, umbilicus and fetal fluid of two naturally infected cows. Veterinary Record 108:500.

4. Cvetnic Z, Spicic S and Curic S (2005). Isolation of Brucella suis biovar 3 from horses in Croatia. Veterinary Record 156:584-585. 


\section{Millat and others}

5. Godfroid J (2002). Brucellosis in wildlife. Revue Scientifique et Technique-Office International des Epizooties 21:277-286.

6. Gul ST and Khan A (2007). Epidemiology and epizootiology of brucellosis: A review. Pakistan Veterinary Journal 27:145-151.

7. Luecro NE, Ayala SM and Escobas GI (2008). Brucella isolated in humans and animals in Latin America from 1968 to 2006. Epidemiology and Infection 136:496-503.

8. Muma JB, Samui KL, Siamudaala VM, Oloya J, Matope G, Omer MK, Munyeme M, Mubita C and Skjerve E (2006). Prevalence of antibodies to Brucella spp. and individual risk factors of infection in traditional cattle, goats and sheep reared in livestock-wildlife interface areas of Zambia. Tropical Animal Health and Production 38:195-206.

9. OIE (2009). Manual of standards for diagnostic tests and vaccines. Bovine brucellosis. Paris: Office International des Epizooties (OIE).

10. Ocholi RA, Bertu WJ and Kwaga JKP (2004). Carpal bursitis associated with Brucella abortus in a horse in Nigeria. Veterinary Record 155:566-567.

11. Omer MK, Skjerve E, Holstads G, Woldhiwet Z and Macmillan AP (2007). Prevalence of antibodies to Brucella spp. in cattle, sheep, goats, horses and camels in the State of Eritrea; influence of husbandry systems. Epidemiology and Infection 125:447-453.

12. Pappas G, Papadimitriou P, Akritidi N, Christou L and Tsianos EV (2006). The new global map of human brucellosis. The Lancet Infectious Diseases 6:91-99.

13. Radostits OM, Gay CC, Blood DC and Hinchcliff KW (2000). Veterinary Medicine, $9^{\text {th }}$ Ed., W. B. Saunders Company Ltd. London, UK.

14. Rahman MS, Faruk MO, Her M, Kim JY, Kang SI and Jung SC (2011). Prevalence of brucellosis in ruminants in Bangladesh. Veterinarni Medicina 56:379-385.

15. Rahman MS, Nuruzzaman M, Ahasan MS, Sarker SS, Chakrabartty A, Nahar A, Uddin MJ, Sarker MAS and Akhter L ((2012). Prevalence of brucellosis in pigs: The first report in Bangladesh. Bangladesh Journal of Veterinary Medicine 10:75-80.

16. Ribeiro MG, Motta RG and Almeida CAS (2008). Brucelose equina: aspectos da doença no Brasil. Revista Brasileira de Reprodução Animal 32:83-92.

17. Roth F, Zinsstag J, Orkhon D, Chimed-Ochir G and Hutton G (2003). Human health benefits from livestock vaccination for brucellosis: Case study. Bulletin of the World Health Organization 81:867-876.

18. Solmaz H, Tutuncu M, Akhan HA, Aksakal A, GulhanT and Boynukara B (2004). Brucellosis inhorses around Van, Turkey. Indian Veterinary Journal 81:748-749.

19. Wadood F, Ahmad M, Khan A, Gul ST and Rehman N (2009). Seroprevalence of brucellosis in horses in and around Faisalabad. Pakistan Veterinary Journal 29:196-198. 